\title{
COSTING METHODS UTILIZATION IN CZECH ENTERPRISES
}

\author{
Boris POPESKO ${ }^{1}$ \\ Tomas Bata university in Zlin, Czech Republic \\ Ostrava Business School plc
}

\begin{abstract}
This paper presents the results of the research of the different types of product costing methods utilization in Czech enterprises performed in the years of 2004, 2007 and 2009. Results of individual surveys are compared, in order to prove the expected tendencies of higher usage of modern costing methods such as Activity-Based Costing, in recent years. First part of the paper refers to previous studies of the enterprise cost structure presented by other authors and illustrates the most important reasons of the individual costing system utilization. Following part of the paper defines the basic research methodology and expected limitation of the study. In final part of the paper, results of the survey are introduced and properly discussed.
\end{abstract}

\section{KEY WORDS}

cost management, costing system, overhead cost, Activity-based costing

\section{JEL CLASSIFICATION}

M20, M41

\section{INTRODUCTION}

Field of the product costing techniques is one of the important features of cost management and management accounting. While the method used for product costing purposes are usually not an object of the any regulations, companies could use any method of product costing and any tape of cost allocation technique. This fact causes a high variety of used costing methods. According to traditional management accounting (Drury 2003, Garrison et al. 2010, Weygandt et al. 2010, Shim and Siegel 2009) product costing methods could be divided in two major categories: job order costing and process costing. These systems differ in the object of the cost assignment. While in job order cost system, the company assigns costs to each job or to batch of goods, in process cost system companies apply costs to similar products that are mass-produced in similar fashion (Weygandt et al. 2010). It is therefore unnecessary to assign costs to individual units of output (Drury 2001). Based on this definition we can expect, that choice to use either job order costing system or process costing system will be more determined by the characteristics of the company production process than by desired way of cost assignment.

\footnotetext{
${ }^{1}$ Correspondence address: doc. Ing. Boris Popesko, Ph.D., boris.popesko@vsp.cz; Tomas Bata University in Zlín, Czech Republic; Vysoká škola podnikání, a. s., Michálkovická 1810/181, 71000 Ostrava - Slezská Ostrava, Czech Republic, www.vsp.cz
} 
Objective of the study was to identify the product costing method according to used method of cost allocation. Traditionally, two different product costing systems are defined, the traditional absorption costing and alternative variable costing (Drury 2001). These two major costing approaches differ from one another, by the degree of costs assigned to the cost driver. Many other methods of product costing are defined in traditional management accounting. Special category of product costing method is the Activity-Based Costing, which was designed in 1980's and became more natural part of enterprise's costing system in recent years. One of the objectives of the study was to identify the level of Activity-Based Costing utilization in Czech Republic.

\section{PRODUCT COSTING METHODS}

Various types of the product costing systems are defined by the academics and practitioners. As mentioned above, product costing methods are not object of any regulation which lead in situation, where users of these systems are free in design, construction and use of the product costing system. Shields (1998) has speculated that there will be an increasing divergence in management accounting practices across industries. Classification of the product costing methods is not general. Product costing methods could be classified in different ways. As mentioned above the costing methods could be classified into job order costing and process costing based on the type of production process. More important classification of the product costing systems is based on cost allocation principles. In this field we can distinguish the traditional absorption costing, variable costing and Activity-Based Costing.

Product costing methods used in organizations went through the relatively important changes in last decades. Al Omiri and Drury (2007) suggests that a need to improve the sophistication of product costing systems has been driven by changes in manufacturing technology, global competition, information costs and customers' demands for greater product diversity. These changes prompted criticisms of the ability of traditional management accounting systems to report sufficiently accurate product costs and $\mathrm{ABC}$ systems were promoted as the solution to overcome the distortions in the product costs reported by traditional costing systems (Cooper, 1988; Kaplan, 1994).

Many studies had been performed in order to analyse the level of utilization of individual costing methods. Most of these studies are focused on the individual segments of the business (Brierley et al, 2007). Many surveys into product costing practice identify the industries making up their sample (e.g. Bright et al., 1992; Drury et al., 1993; Lamminmaki and Drury, 2001) and others have identified industries making up their samples in Activity-Based Costing (ABC) research (e.g. Cobb et al., 1993; Gosselin, 1997).

Performed studies had the focus on different industry segments and used different structure of questions, which make even more difficult to declare any common results. Brierley's (2007) study performed in England shows that $20.7 \%$ of companies do not include overhead costs in product costs, while $33.6 \%$ of companies uses or is open to use ABC. Similar study made by Al Omiri and Drury (2007) in 1000 UK companies showed very similar result: $35 \%$ of companies use traditional absorption costing system, $23 \%$ of companies use variable (direct) costing system and $29 \%$ of the companies use ABC system.

Many studies have been reported in field of ABC extent. Cokins (2003) suggest that significant variations in usage of $\mathrm{ABC}$ both within the same country and across different countries have been reported. These differences may arise from the difficulty to define precisely the difference between traditional costing systems and $\mathrm{ABC}$ systems and the specific time period when the surveys were actually undertaken. The same limitations could play role in distinguishing other types of costing systems such as absorption and direct costing. 
Drury (2003) suggests that performed survey evidence points at an increasing interest in ABC over the last two decades. In the UK, surveys in the early 1990s reported adoption rates around 10\% (Innes and Mitchell, 1991), similar adoption rates of 10\% were found in Ireland (Clarke, 1992) and 14\% in Canada (Armitage and Nicholson, 1993). In the USA Green and Amenkhienan (1992) claimed that $45 \%$ of firms used $\mathrm{ABC}$ to some extent. More recent studies suggest higher $\mathrm{ABC}$ adoption rates. In the UK reported usage was 29\% (Al Omiri and Drury, 2007). In the USA Shim and Stagliano (1997) was reported usage rate $27 \%$.

Large surveys related to the ABC adoption had been performed in mid 1990s. Report usage rates from mainland Europe are 19\% in Belgium (Brugemann et al, 1996), and 6\% in Finland in 1992, $11 \%$ in 1993 and 24\% in 1995 (Viertanen et al, 1996). Low usage rates have been reported in Denmark (Israelsen et al, 1996) in Sweden (Ask et al, 1996) and Germany (Scherrer, 1996). Activity-based techniques do not appear to be adopted in Greece (Ballas and Venieris, 1996), Italy (Barbato et al., 1996) or Spain (Saez-Torrecilla, 1996).

Along with the relatively strong differences between used product costing methods in different surveys, many authors points at the dependence of the used method of product costing on the type of the organization and organization cost structure. Study performed by Lawson et al. (2009) showed very strong relation between indirect cost portion and cost management methods used. Study proves the fact, that best-practice organizations have a much higher level of indirect costs, requiring them to have a costing system that can more accurately allocate these costs in a relevant, reliable, and reasonable manner. The greater use and appreciation of Activity-Based Costing by the best practice companies can be attributed to their greater need for better costing system. Strumactickas and Valanciene (2009) proved that the applicable instruments of management accounting depend on an organization type. Their study indicates that Market Creators use the least tools and Value Creators have most of them on an average. Market creators are strategically oriented young companies, which reach their "blossom" phase and start to stabilize, while value creator is mainly related to the getting out of stabilization phase.

Another reason which drives the selection of the product costing system is the structure of the products, customers and performed activities. Many authors (Cokins, 2001; Stanek 2003) refer that application of more sophisticated product costing method, such as Activity-based costing, is most effective in enterprises with complex structure of the products, customers and activities. Abernethy et al.(2009) shows how product diversity and cost structure influence the design of costing systems.

\subsection{Specifics of the product costing in Czech perspective}

Use of the management accounting techniques in Czech Republic in the second half of $20^{\text {th }}$ century had several specifics caused by political environment. Orientation on central planned economy led to the establishment of integral system for company management. Methodology of the product costing was regulated by the statutory rules in order to fulfil the needs of central planned economy. This costing technique was based on traditional absorptions costing principles and used three different types of overheads (production, administrative and sales). In 1966, the regulations of the unified costing rules were accepted and in 1971 act of unified social-economic information system finished the complex regulation of the management accounting techniques in state owned enterprises (Lanča and Sedláček, 2005).

Change of the politic system in 1989 caused the transformation from central planned economy into free market economy. In this situation no regulations related to the system of the management accounting were furthermore demanded. The change of the political system doesn't mean radical change in the management accounting practices. Companies started very slow process of adoption 
of diverse costing techniques. Anyway, many companies keep in use the traditional techniques known from 1970s.

\section{RESEARCH OBJECTIVES AND USED METHODOLOGY}

Research focused on the product costing method application in Czech enterprises had been performed in years 2004-2009. Three individual surveys had been performed: first in 2004, second in 2007 and last in 2009. The performed researches has been focused on the more aspects of the management accounting practices such as cost structure, used methods of product costing, budgeting practices etc. This paper reports the results of the research focusing on used product costing techniques. Performance of the similar researches in different periods of time allows the analysis of the product costing method utilization trends. The expectations, based on the foreign studies, were in increasing usage of the sophisticated costing methods such as Activity-based costing and decreasing use of traditional absorption costing methods. Foreign experience shows, that relative use of modern costing systems is gradually increasing in long term period. Expectation about absolute portion of use of different costing methods was different than in foreign studies. Because of the above mentioned specifics of the costing process before 1989 and slower adoption of progressive managerial techniques, considerably lower usage of $\mathrm{ABC}$ was expected in the study.

The hypothesis about the low usage of ABC techniques and about their increasing use in Czech enterprises was tested by the questionnaire survey and by the statistical comparison of the data gathered from different time periods.

Data from three questionnaire surveys has been analyzed in the research in order to get better and more accurate results and also because of a need to compare the evolution of the researched indicators. First questionnaire survey was made in 2004, when 116 questionnaires had been evaluated (Popesko 2005). Similar research was made in 2007. The structure of the questionnaire was focused on the same objectives as in 2004. 96 questionnaires have been gathered and analyzed (Popesko \& Novak 2008). Final questionnaire survey was performed in 2009 as a part of extended research focused on costing methods use in Czech enterprises (Novak 2009). Finally 77 questionnaires have been processed. Enterprises of different sizes have been researched within the individual surveys. Table 1 shows the structure of statistic file.

Table 1. Structure of the researched enterprises

\begin{tabular}{|c|c|c|}
\hline YEAR/ENTERPRISE CATEGORY & TOTAL & RELATIVE \\
\hline \multicolumn{3}{|l|}{2004} \\
\hline Small & 9 & $7,76 \%$ \\
\hline Medium & 55 & $47,41 \%$ \\
\hline Large & 52 & $44,83 \%$ \\
\hline \multicolumn{3}{|l|}{2007} \\
\hline Small & 38 & $39,58 \%$ \\
\hline Medium & 32 & $33,33 \%$ \\
\hline Large & 26 & $27,08 \%$ \\
\hline \multicolumn{3}{|l|}{2009} \\
\hline Small & 8 & $10,39 \%$ \\
\hline Medium & 42 & $54,55 \%$ \\
\hline Large & 27 & $35,06 \%$ \\
\hline
\end{tabular}




\section{RESULTS}

As mentioned above, first research survey has been made in 2004 where 116 manufacturing enterprises have been investigated. The objective of the survey was an identification of the used product costing methods in Czech enterprises. Results of the survey are depicted in table 2. Total sum of answers doesn't give the number of surveyed enterprises, because some of the respondents use more than one method.

Table 2. Product costing methods used in 2004

\begin{tabular}{||l|c|c||}
\hline USED PRODUCT COSTING METHOD & TOTAL & RELATIVE \\
\hline Do not use any product costing method & 7 & $5.98 \%$ \\
\hline Division costing & 5 & $4.27 \%$ \\
\hline Traditional absorption costing & 36 & $30.77 \%$ \\
\hline Joint and by-product costing & 2 & $1.71 \%$ \\
\hline Standard costing & 50 & $42.74 \%$ \\
\hline Variable costing & 35 & $29.91 \%$ \\
\hline ABC/M & 6 & $5.13 \%$ \\
\hline Other & 11 & $9.40 \%$ \\
\hline
\end{tabular}

(Source: Popesko, 2005)

The survey proved relatively high use of traditional absorption costing (over 30\%) and high use of variable (direct) costing method (30\%). Relatively surprising was the use of the standard costing method. Because this method in not pure allocation method, but rather cost control method, it was mostly marked along with the other costing methods. Use of the Activity-based costing and management techniques were identified by $5.1 \%$ enterprises.

Very similar research had been performed in 2007. The performed research, which was primarily oriented on the complex management accounting techniques used by Czech enterprises, contained the same questions related to the used product costing methods as research performed in 2004, in order to allow the comparison with 2004 research. Results of the survey are depicted in table 3.

Table 3. Product costing methods used in $\mathbf{2 0 0 7}$

\begin{tabular}{||l|c|c||}
\hline USED PRODUCT COSTING METHOD & TOTAL & RELATIVE \\
\hline Do not use any product costing method & 5 & $5.21 \%$ \\
\hline Division costing & 9 & $9.38 \%$ \\
\hline Traditional absorption costing & 30 & $31.25 \%$ \\
\hline Joint and by-product costing & 4 & $4.17 \%$ \\
\hline Standard costing & 39 & $40.63 \%$ \\
\hline Variable costing & 23 & $23.96 \%$ \\
\hline ABC/M & 5 & $5.2 \%$ \\
\hline Other & 2 & $2.1 \%$ \\
\hline
\end{tabular}

(Source: Popesko and Novak, 2008)

Despite relatively different structure of the researched enterprises (table 1), survey performed in 2007 showed very similar results as the study performed in 2004. This similarity could support the 
relevance of the performed studies based on the relatively low number of respondents. Two major product cost techniques showed similar utilization as in 2004, the traditional absorption costing $(31.5 \%)$ and variable costing little lower volume (24\%). The study showed again relatively high usage of the standard costing method very often used along with other costing methods. Utilization of $\mathrm{ABC}$ is almost the same $(5.2 \%)$.

Similar data were gathered in questionnaire survey performed in 2009. Results of the survey are depicted in table 4.

Table 4. Product costing methods used in 2009

\begin{tabular}{||l|c|c||}
\hline \hline USED PRODUCT COSTING METHOD & TOTAL & RELATIVE \\
\hline Do not use any product costing method & 3 & $3,90 \%$ \\
\hline Division costing & 2 & $2,60 \%$ \\
\hline Traditional absorption costing & 31 & $40,26 \%$ \\
\hline Joint and by-product costing & 0 & $0,00 \%$ \\
\hline Standard costing & 8 & $10,39 \%$ \\
\hline Variable costing & 4 & $5,19 \%$ \\
\hline ABC/M & 6 & $7,79 \%$ \\
\hline Other & 30 & $38,96 \%$ \\
\hline
\end{tabular}

(Source: Novak, 2009)

Result of the survey is relatively different form previous studies. Most common product costing method is again the traditional absorption costing. Survey showed relatively low use of variable costing. Some of the users of variable (direct costing) could be in the category "other" because of various description of this type of product costing method in practice. The use of $A B C / M$ was very similar to the expectations. Result showed that use of this method is slightly increasing.

\section{DISCUSSION AND CONCLUSIONS}

Above described results qualify the authors to several statements. Most used type of product costing method in Czech manufacturing enterprises is traditional absorption costing. Surprising result was the relatively increasing use of this type of product costing, together with the relative lower use of variable (direct) costing. Explanation of this could be tendencies of manufacturing companies to adopt the full costing method in order to better support of pricing decisions. The variable costing method seems to be relatively popular in Czech enterprises in 1990's. Temporary adoption of the absorption costing method could be accepted as the interpretation of the survey results.

Expected results have been indicated in the Activity-based methods utilization. Survey showed relatively low use of these methods with comparison to other European countries. The study also proved increasing use of $\mathrm{ABC} / \mathrm{M}$ in Czech manufacturing enterprises. The study also showed that the utilization of Activity-based techniques is relatively more frequent in large enterprises, than in small and medium enterprises. The large companies were ABC users in 5 out of the 6 cases in 2004, in 4 out of the 5 cases and in 2 out of the 6 cases in 2009.

The study could have limitations in number of researched enterprises, in understanding of question by the respondents or in ability of respondents to provide undistorted answers in the survey. Despite that fact it provides the actual overview of the used product costing methods in Czech 
manufacturing enterprises during 2000's. The comparison of the individual survey results could also depict the tendencies in product costing method utilization.

\section{REFERENCES}

Abernethy, M. A., Lillis, A.M., Brownell P., Carter, P. (2001) Product diversity and costing system design choice: field study evidence, Management Accounting Research, 2001, 12, 261-279

Al Omiri, M., Drury, C. (2007) A survey of factors influencing the choice of product costing systems in UK organizations, Management Accounting Research 18, p. 399-424

Armitage, H.M., Nicholson, R. (1993) Activity-based costing: a survey of Canadian practice, Issue paper No. 3, Society of Management Accountants of Canada

Ask, U., Ax, C., Jonsson, S., (1996), Cost management in Sweden: from modern to post-modern, in Bhimani, A. (ed), Management Accounting: European Perspectives, Oxford, Oxford University Press, pp. 199-217

Ballas, A., Venieris, G. (1996) A survey of management accounting practices in Greek firms, in Bhimani, A. (ed), Management Accounting: European Perspectives, Oxford, Oxford University Press, pp. 123-139

Barbato, M.B., Collini, P, Quagli (1996) Management accounting in Italy, in Bhimani, A. (ed), Management Accounting: European Perspectives, Oxford, Oxford University Press, pp. 140163

Brierley, J.A., Cowton, C.J., Drury, C. (2007) „Product Costing Practices in Different Manufacturing Industries: A British Survey”, International Journal of Management, Dec 2007. vol. 24, Iss. 4; pg. 667, 10 pgs

Bright, J., Davies, R.E., Downes, CA. and Sweeting, R.C. (1992) The Deployment of Costing Techniques and Practices: A UK Study, Management Accounting Research, pp. 201-211

Brugemann, W., Slagmulder, R., Waeytens, D. (1996) Management accounting changes; the Belgian experience, in Bhimani, A. (ed), Management Accounting: European Perspectives, Oxford, Oxford University Press, pp. 1-30

Clarke, P.J. (1992) Management Accounting Practices and Techniques in Irish Manufacturing Firms, The $15^{\text {th }}$ Annual Congress of the European Accounting Association, Madrid, Spain

Cobb, I., Innes, J., Mitchell, F. (1993) Activity-based Costing Problems: The British Experience, Advances in Management Accounting, pp. 63-83

Cooper, R. (1988) „The rise of activity-based costing-part three: how many cost drivers do you need, and how do you select them?" Journal of Cost Management in Manufacturing Industry, 34-46.

Drury, C, Braund, S., Osborne, P. and Tayles, M. (1993) A Survey of Management Accounting Practices in UK Manufacturing Companies, London, Chartered Association of Certified Accountants

Drury, C., Management and Cost Accounting, Fifth Edition, Thomson Learning 2001, ISBN 186152-536-2

Garrisin, R.H., Noreen, E.W., Brewer, P.C., Managerial Accounting, McGraw/Irwin New York 2010, ISBN 978-0-07-337961-6

Gosselin, M. (1997) „The Effect of Strategy and Organizational Structure on the Adoption and Implementation of Activity-based Costing, Accounting”, Organizations and Society, pp. 105122

Green, F.B., Amenkhienan, F.E. (1992) „Accounting innovations: A cross sectional survey of manufacturing firms", Journal of Cost Management of the manufacturing industries, Spring 58-64.

Innes, J., Mitchell, F. (1991) „ABC: A survey of CIMA members”, Management Accounting, October, 28-30 
Israelsen, P., Anderson, M., Rohde, C., Ssorensen, P.E. (1996) „Management Accounting in Denmark: theory and practice", in Bhimani, A. (ed), Management Accounting: European Perspectives, Oxford, Oxford University Press, pp. 31-53

Kaplan, R.S. (1994) „Management accounting (1984-1994): development of new practice and theory.", Management Accounting Research 5, 247-260.

Lamminmaki, D., Drury, C. (2001) „A Comparison of New Zealand and British Product Costing Practices", The International Journal of Accounting, pp. 329-347

Lanca, J., Sedlacek, J. (2005) Manažerské účetnictví. 1.vyd. Brno: Masaryk University. 172 p., ISBN 80-210-3643-5

Lawson, R., Stratton, W., Desroches, D., Hatch, T., „Best practices in cost and profitability systems", Cost Management, Sep/Oct 2009; vol. 23, 5; pg. 13

NOVÁK, P., Problematika ř́zení a alokace režijních nákladi̊ v podmínkách výrobních podniků, disertation thesis, Univerzita Tomáše Bati ve Zlíně 2009

POPESKO, B., Aplikace procesního řízení nákladi̊ v podmínkách českých organizací, dissertation thesis, Univerzita Tomáše Bati ve Zlíně 2005, ISBN 80-80-7318-280-7

POPESKO, B., NOVÁK, P., Activity-Based Costing applications in the Czech Republic, Lex et Scientia International Journal Nr. XV Vol.1/2008, Nicolaue Tulescu University from Bucharest, ISSN 1583-039X

Saez-Torrecilla, A., Fernandez-Fernandez, A., Texeira-Quiros, J., Vaquera-Mosquero, M., (1996), „Management accounting in Spain: trends in thought and practice”, in Bhimani, A. (ed), Management Accounting: European Perspectives, Oxford, Oxford University Press, pp. 180190

Scherrer, G., (1996), „Management Accounting: a German perspective”, in Bhimani, A. (ed), Management Accounting: European Perspectives, Oxford, Oxford University Press, pp. 100122

Shields, M.D., (1998), „Management Accounting Practices in Europe: A Perspective from the States", Management Accounting Research, pp. 501-513

Shim, E., Stagliano, A., (1997), „A survey of US manufacturers on implementation of ABC”, Journal of Cost Management, March/April, 39-41

Shim, J.K., Siegel, J.G., Modern Cost Management \& Analysis, Barron’s Business Library 2009, ISBN 978-0-7641-4103-4

Viertanen, K., Malmi, T., Vaivio, J., Kasanen, E., (1996), „Drivers of management Accounting in Finland", in Bhimani, A. (ed), Management Accounting: European Perspectives, Oxford, Oxford University Press, pp. 218-241

Weigandt, J.J., Kimmel, P.D., Donald, E.K., (2010), Managerial Accounting, John Wiley \& Sons, ISBN-13 978-0-470-47714-4 